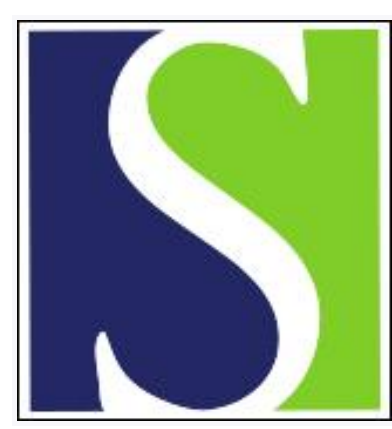

Scand J Work Environ Health 1997;23(4):281-288

https://doi.org/10.5271/sjweh.221

Issue date: Aug 1997

\section{Reproductive toxicity of 2-bromopropane in Sprague Dawley} rats

by Yu IJ, Chung YH, Lim CH, Maeng SH, Lee JY, Kim HY, Lee SJ, Kim CH, Kim TG, Lim CH, Park JS, Moon YH

Key terms: anemia; azoospermia; epididymis; hematopoietic toxicity; isopropyl bromide; leukopenia; oligospermia; testis

This article in PubMed: www.ncbi.nlm.nih.gov/pubmed/9322819

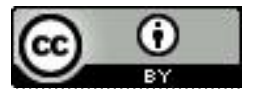




\title{
Reproductive toxicity of 2-bromopropane in Sprague Dawley rats
}

\author{
by II Je Yu, PhD, ${ }^{1}$ Yong Hyun Chung, VMD, ${ }^{1}$ Cheol Hong Lim, MSc, ${ }^{1}$ Seung Hee Maeng, MPH, ${ }^{1}$ \\ Jun Yeon Lee, MSc, ${ }^{1}$ Hyeon Yeong Kim, MSc, ${ }^{1}$ Soo Jin Lee, BSc, ${ }^{1}$ Chung Hyun Kim, BSc, ${ }^{1}$ \\ Tae Gyun Kim, Bsc, ${ }^{1}$ Chang Hyeong Lim, VMD, ${ }^{1}$ Jung Sun Park, MD, ${ }^{1}$ Young Hahn Moon, MD ${ }^{1}$
}

\begin{abstract}
Yu IJ, Chung YH, Lim CH, Maeng SH, Lee JY, Kim HY, Lee SJ, Kim CH, Kim TG, Lim CH, Park JS, Moon YH. Reproductive toxicity of 2-bromopropane in Sprague Dawley rats. Scand J Work Environ Health 1997;23(4): $281-8$.

Objectives In an effort to clarify the mass intoxication of workers at an electronic company in Korea, the possible causative chemical for reproductive toxicity, 2-bromopropane (2BP), was investigated.

Methods 2BP was tested through the use of repeated dose experiments among male Sprague Dawley rats. Ten rats were assigned to each treatment group. Vehicle control olive oil and $2 \mathrm{BP}$ concentrations of $125 \mathrm{mg} / \mathrm{kg}$, $250 \mathrm{mg} / \mathrm{kg}$, and $500 \mathrm{mg} / \mathrm{kg}$ were injected into the intraperitoneum on 28 consecutive days.

Results The rats showed significant decreases in body weight depending on the 2BP dose. The right and left testes showed typical weight loss depending on the dose of 2BP. The red blood cells, hemoglobin, and hematocrit showed some degree of decline with the high dose. The amount of hemoglobin, the mean platelet volume, the number of white blood cells, and the number of lymphocytes decreased significantly with the high dose, while the number of granulocytes and monocytes had a tendency to decrease depending on the dose of 2BP. The histopathology of the testes treated with the middle and high 2BP dose showed a typical patch appearance with severely depleted atrophic tubules, exhibiting germ cell necrosis of spermatogonia and spermatocytes in the seminiferous tubules. Leydig cell hyperplasia or hypertrophy in the interstitial tissue was also noticeable. The epididymis showed some degree of atrophy with vacuolization of the epididymal epithelium.

Conclusions The testes are the main target organs tested for 2BP toxicity. 2BP also affect the hematopoietic system and thus induces leukopenia and normocytic anemia. Besides the reproductive organs and the hematopoietic system, no significant toxicity has been found.
\end{abstract}

Key terms anemia, azoospermia, epididymis, hematopoietic toxicity, isopropyl bromide, leukopenia, oligospermia, testis.

A recent case series study on the mass intoxication of workers at an electronic factory in Korea indicated that 2-bromopropane (2BP; isopropyl bromide) was the possible causative chemical for reproductive and hematopoietic toxicity $(1-3)$. The case report indicated that 17 of 25 female workers showed ovarian dysfunction accompanied by amenorrhea and severe anemia, and 6 of 8 male workers had oligospermia or azoospermia (1). One worker with azoospermia also had pancytopenia (1). The duration of $2 \mathrm{BP}$ exposure of the workers varied from 4 months to 16 months with an average duration of 10 months (1--2). The reproductive and general toxicity of 2BP has never been documented well. 2BP has been used in operating tact switch manufacturing in an electronic company as a substitute for Freon 113 (trichloro- trifluoroethane). The workers were known to be exposed to a cleaning solution which was a mixture $(1: 180)$ of the commercial product SPG-6AR and solvent 5200. SPG$6 \mathrm{AR}$ was composed mainly of 2BP $(60.7 \%)$, heptane $(33 \%)$, and 1,1,1-trichloroethane (1.55\%) and other chemicals (eg, 1,2-dof $<1 \%$ ). The main component of solvent 5200 was $2 \mathrm{BP}(99.1 \%)$, and it also contained 1,2-dibromopropane $(0.2 \%)(2)$. In addition, this chemical has been used as a substitute for trichloroethylene to extract the contents of asphalt mixtures, described in the pavement test method (4). The material safety data sheet on 2BP describes $2 \mathrm{BP}$ as a rather safe chemical with a median lethal dose $\left(\mathrm{LD}_{50}\right)$ of $4837 \mathrm{mg} / \mathrm{kg}$ and a $50 \%$ lethal concentration $\left(\mathrm{LC}_{50}\right)$ of $36 \mathrm{~g} / \mathrm{m}^{3}(5)$. In our recent study, the $\mathrm{LC}_{50}$ of $2 \mathrm{BP}$ was $31171 \mathrm{ppm}$ for ICR (Insti-

1 Department of Industrial Toxicology, Industrial Health Research Institute, Korea Industrial Safety Corporation, Inchon, Korea.

Reprint requests to: Dr Il Je Yu, Industrial Chemical Research Center, 104-8 Moonji-dong, Yusung-gu, Daejon, 305-380, Korea. 
tute for Cancer Research) mice (2). The mutagenesis of 2BP has been investigated with the Ames test, a chromosome aberration test, and a micronucleus test. Although 2BP tested positive in the Ames test, the results proved negative for both the micronucleus test using experimental animals and the chromosome aberration test using Chinese hamster lung cells cultured in vitro (3). Two laboratories conducted acute oral toxicity tests and found the lethal dose of 2BP to be lower than $2000 \mathrm{mg} / \mathrm{kg}$, but no reproductive toxicity was found $(6-8)$.

In this report, we describe our recent findings on the reproductive toxicity, as well as other toxicities, of 2BP in a 28-day repeated dose experiment with rats.

\section{Materials and methods}

\section{Test chemicals}

2BP was purchased from Tokyo Kasei Co, Ltd (Japan). The chemical purity tested, by mass spectrophotometric analysis, was essentially $99 \%$. The gas chromatographic (GC/FID) analysis did not detect any extraneous peaks. No decomposition of the compound was noted during storage. 2BP was mixed with vehicle olive oil (Sigma, United States) and injected into the intraperitoneum of the rats.

\section{Animals}

Ten-week-old male, specific pathogen-free Sprague Dawley rats were purchased from the Daehan Animal Center (Korea). The animals were acclimatized for 2 weeks before the start of the experiment. The animal chamber, temperature, and relative humidity were regulated within limits of $23 \pm 2^{\circ} \mathrm{C}$ and $55 \pm 7^{\circ} \mathrm{C}$, respectively, in a safety clean rack (MJ-721 CS(P), Myung-Jin, Korea). The rats were maintained in a 12 -hour light/dark cycle. Purina rodent chow (Korea) and filtered water were offered ad libitum. Sets of 3-4 rats were divided into polycarbonate cages. Ten rats of each set were blocked by body weight and randomly assigned to 1 of 4 groups (10 per sex per group) 7 days prior to the initiation of the experiment. The dose levels per body weight were 0 (control), 125 (low dose), 250 (middle dose), and 500 (high dose) $\mathrm{mg} / \mathrm{kg}$. 2BP dissolved in vehicle olive oil was injected into the intraperitoneum 6 times per week for 4 weeks. On the day of grouping, the mean body weight was approximately $300 \mathrm{~g}$ for each male group. Animals were examined daily during weekdays for evidence of any treatment-related effects, including respiratory, dermal, behavioral, nasal, or genitourinary changes suggestive of irritancy. Food consumption was measured every 3rd day during the 28 days of treatment. Body weights were evaluated at the time of purchase, grouping, twice a week after the initiation of the experiment, and before the necropsy.

\section{Biochemistry and hematology}

The animals were nearly 16 weeks old when the necropsies were processed. They were made to fast 1 day before the necropsy. On the last study day, the animals were briefly anesthetized with ether, and blood was collected from the abdominal aorta. The blood was then analyzed for aspartate aminotransferase, alanine aminotransferase, alkaline phosphatase, glucose, urea nitrogen in blood, total protein, cholesterol creatinine, and total bilirubin concentration. The blood was further analyzed for red blood cell counts, white blood cell counts, hemoglobin concentration, hematocrit, mean corpuscular volume, mean corpuscular hemoglobin, differential smear evaluation, and platelet counts.

\section{Pathology and organ weight}

After the collection of blood, the rats were sacrificed by cervical dislocation. The adrenals, ovaries, testes, heart, lungs, kidneys, spleen, liver and brain were removed, weighed, and fixed in a $10 \%$ formalin solution containing neutral phosphate buffered saline. Aside from the liver, kidney and reproductive organs, the other organs show-

Table 1. Relative organ weights of the male rats treated with 2-bromopropane (2BP) for 28 days and of the control rats. ${ }^{2}$

\begin{tabular}{|c|c|c|c|c|c|c|c|c|c|c|c|c|c|c|}
\hline \multirow[t]{2}{*}{ 2BP dose } & \multicolumn{2}{|c|}{$\begin{array}{l}\text { Initial body } \\
\text { weight }(g)\end{array}$} & \multicolumn{2}{|c|}{$\begin{array}{c}\text { Terminal body } \\
\text { weight }(g)\end{array}$} & \multicolumn{2}{|c|}{$\begin{array}{c}\text { Adrenal, right } \\
\text { (mg) }\end{array}$} & \multicolumn{2}{|c|}{$\begin{array}{c}\text { Adrenal, left } \\
(\mathrm{mg})\end{array}$} & \multicolumn{2}{|c|}{$\begin{array}{c}\text { Testis, right } \\
\text { (mg) }\end{array}$} & \multicolumn{2}{|c|}{$\begin{array}{c}\text { Testis, left } \\
(\mathrm{mg})\end{array}$} & \multicolumn{2}{|c|}{$\begin{array}{l}\text { Heart } \\
(\mathrm{mg})\end{array}$} \\
\hline & Mean & SD & Mean & SD & Mean & SD & Mean & SD & Mean & $\mathrm{SD}$ & Mean & $\mathrm{SD}$ & Mean & SD \\
\hline $\begin{array}{l}125 \mathrm{mg} \\
(\mathrm{N}=10)\end{array}$ & 300.7 & 12.7 & 352.5 & 11.8 & 12.8 & 1.6 & 13.0 & 3.3 & 465.6 & 38.4 & 467.9 & 36.7 & 375.0 & $13.8^{*}$ \\
\hline $\begin{array}{l}250 \mathrm{mg} \\
(N=10)\end{array}$ & 300.3 & 12.7 & 330.4 & $10.7^{*}$ & 16.1 & $1.7^{*}$ & 15.5 & $1.8^{*}$ & 401.3 & $49.0^{*}$ & 402.9 & $49.3^{*}$ & 355.8 & $18.3^{*}$ \\
\hline $\begin{array}{l}500 \mathrm{mg} \\
(\mathrm{N}=10)\end{array}$ & 301.4 & 13.2 & 289.8 & $16.0^{*}$ & 18.4 & $3.6^{*}$ & 16.3 & $3.5^{\star}$ & 378.6 & $74.0^{*}$ & 329.8 & $88.8^{*}$ & 344.2 & 27.6 \\
\hline $\begin{array}{l}\text { Control } \\
(N=10)\end{array}$ & 300.5 & 14.3 & 356.7 & 16.1 & 14.8 & 4.0 & 12.1 & 2.8 & 465.6 & 65.0 & 475.5 & 30.7 & 334.5 & 29.8 \\
\hline
\end{tabular}

a Organ weight was normalized to $100 \mathrm{~g}$ of body weight.

* $P<0.05$ versus control. 
ing significant weight changes were embedded in paraffin, stained with hematoxylin and eosin, and examined by light microscopy.

\section{Statistical analysis}

A 2-way analysis of variance and Duncan's multiple range test were used to compare the body weight, the organ weight, and blood biochemistry and hematology values of the controls with the other 3 groups.

\section{Results}

\section{Animal observation}

The 2BP-treated animals fell into a dizzy state with 2 rats looking at each other and becoming lethargic after 15 minutes of treatment.

\section{Body weight development}

The rats treated with $2 \mathrm{BP}$ showed significant decreases $(\mathrm{P}<0.05)$ in body weight depending on the dose of $2 \mathrm{BP}$ during the 28 days of the experiment (figure 1). The low dose treatment showed similar body weight development as seen in the control group, while the middle and high doses of $2 \mathrm{BP}$ treatment resulted in a significant decline in body weight $(\mathrm{P}<0.05)$.

\section{Terminal organ weight}

The terminal organ weights are summarized in table 1. Several organs showed a statistically significant $(\mathrm{P}<0.05)$ weight loss. In male rats, the right and left testes showed typical weight losses depending on the dose of $2 \mathrm{BP}$. The dose-dependent weight loss of testes was evident when the testes weight was normalized by $100 \mathrm{~g}$ of body weight (table 1). The relative weight losses of testes were $14-15 \%$ for the middle dose group and $19-30 \%$ for the high-dose group $(\mathrm{P}<0.05)$. Besides the testes, no other organs showed any significant organweight loss.

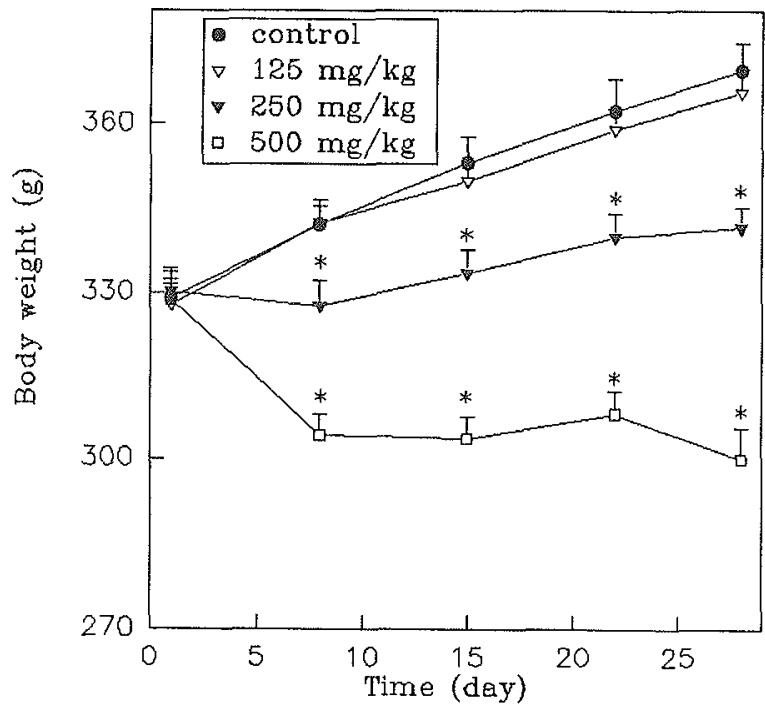

Figure 1. Body weight changes of male rats during 28 days of $2 \mathrm{BP}$ treatment. Male rats were treated with $0,125,250$, and $500 \mathrm{mg} / \mathrm{kg}$ of $2 \mathrm{BP}$ for 28 days. Ten male rats were assigned to each treatment group. Body weight was measured at the time of the grouping and twice a week after the initiation of the experiment. ( ${ }^{*} P<0.05$ versus control)

\section{Blood chemistry and hematological examination}

The red blood cell count and hematocrit showed some degree of decline in the high-dose rats, though not to a significant level (table 2). The red cell distribution width increased in the high-dose rats, though not to a significant level (table 2), whereas the hemoglobin and mean platelet volume significantly decreased $(\mathrm{P}<0.05)$ (table 2). The number of white blood cells significantly decreased in the high-dose group $(\mathrm{P}<0.05)$ (table 2$)$, and the number of granulocytes and monocytes had a tendency to decrease depending on the dose. This tendency was more apparent in the analysis of lymphocyte numbers $(\mathrm{P}<0.05)($ table 2$)$.

The blood chemical analysis of the 2BP-treated animals did not show any significant increase in aspartate aminotransferase, alanine aminotransferase, or alkaline phosphatase in a dose-dependent manner (table 3). In

\begin{tabular}{|c|c|c|c|c|c|c|c|c|c|c|c|c|c|}
\hline \multicolumn{2}{|c|}{$\begin{array}{c}\text { Lung, right } \\
\text { (mg) }\end{array}$} & \multicolumn{2}{|c|}{$\begin{array}{l}\text { Lung, left } \\
\text { (mg) }\end{array}$} & \multicolumn{2}{|c|}{$\begin{array}{l}\text { Kidney, right } \\
\text { (mg) }\end{array}$} & \multicolumn{2}{|c|}{$\begin{array}{l}\text { Kidney, left } \\
\text { (mg) }\end{array}$} & \multicolumn{2}{|c|}{$\begin{array}{l}\text { Spleen } \\
\text { (mg) }\end{array}$} & \multicolumn{2}{|c|}{$\begin{array}{l}\text { Liver } \\
\text { (mg) }\end{array}$} & \multicolumn{2}{|c|}{$\begin{array}{l}\text { Brain } \\
\text { (mg) }\end{array}$} \\
\hline Mean & SD & Mean & SD & Mean & $\mathrm{SD}$ & Mean & $S D$ & Mean & SD & Mean & SD & Mean & SD \\
\hline 284.6 & 34.3 & 146.4 & 21.1 & 371.1 & $21.2^{*}$ & 367.1 & 19.0 & 206.8 & 8.3 & 2899.8 & 100.1 & 560.3 & 34.2 \\
\hline 281.3 & 16.6 & 153.2 & 5.7 & 389.9 & 75.0 & 359.0 & 23.0 & 203.2 & 23.4 & 2877.3 & 137.9 & 576.7 & 42.1 \\
\hline 327.6 & $38.7^{*}$ & 181.2 & $27.8^{*}$ & 349.0 & 24.0 & 349.0 & 26.1 & 253.2 & $51.0^{*}$ & 3159.7 & $127.6^{*}$ & 664.1 & $42.1^{*}$ \\
\hline 264.0 & 15.7 & 141.9 & 10.9 & 350.4 & 24.3 & 345.8 & 19.8 & 204.5 & 14.1 & 2815.3 & 101.2 & 554.1 & 25.5 \\
\hline
\end{tabular}


Table 2. Hematology data for the male rats treated with 2-bromopropane (2BP) for 28 days and of the control group.

\begin{tabular}{|c|c|c|c|c|c|c|c|c|c|c|c|c|c|c|c|c|}
\hline \multirow[t]{2}{*}{ 2BP dose } & \multicolumn{2}{|c|}{$\begin{array}{c}\text { White blood } \\
\text { cell count } \\
\left(10^{3} / \mathrm{mm}^{3}\right)\end{array}$} & \multicolumn{2}{|c|}{$\begin{array}{c}\text { Lymphocyte } \\
\text { count } \\
\left(10^{3} / \mathrm{mm}^{3}\right) \\
\end{array}$} & \multicolumn{2}{|c|}{$\begin{array}{c}\text { Monocyte } \\
\text { count } \\
\left(10^{3} / \mathrm{mm}^{3}\right) \\
\end{array}$} & \multicolumn{2}{|c|}{$\begin{array}{c}\text { Granulocyte } \\
\text { count } \\
\left(10^{3} / \mathrm{mm}^{3}\right) \\
\end{array}$} & \multicolumn{2}{|c|}{$\begin{array}{c}\text { Red blood cell } \\
\text { count } \\
\left(10^{6} / \mathrm{mm}^{3}\right) \\
\end{array}$} & \multicolumn{2}{|c|}{$\begin{array}{l}\text { Hemoglobin } \\
\text { concentration } \\
(\mathrm{g} / \mathrm{dl}) \\
\end{array}$} & \multicolumn{2}{|c|}{$\begin{array}{l}\text { Hematocrit } \\
\text { concentration } \\
(\%)\end{array}$} & \multicolumn{2}{|c|}{$\begin{array}{l}\text { Corpuscular } \\
\text { volume } \\
\left(\mu^{3}\right)\end{array}$} \\
\hline & Mean & SD & Mean & $S D$ & Mean & $S D$ & Mean & SD & Mean & SD & Mean & SD & Mean & SD & Mean & SD \\
\hline $\begin{array}{l}125 \mathrm{mg} \\
(\mathrm{N}=10)\end{array}$ & 8.57 & 1.51 & 7.38 & 1.11 & 0.67 & 0.39 & 0.52 & 0.13 & 10.00 & 3.80 & 19.11 & 4.66 & 54.15 & 20.20 & 54.29 & 0.95 \\
\hline $\begin{array}{l}250 \mathrm{mg} \\
(\mathrm{N}=10)\end{array}$ & 7.79 & 2.02 & 6.62 & 1.04 & 0.65 & 0.65 & 0.52 & 0.64 & 8.32 & 1.84 & 17.36 & 3.36 & 45.31 & 10.46 & 54.42 & 1.20 \\
\hline $\begin{array}{l}500 \mathrm{mg} \\
(\mathrm{N}=10)\end{array}$ & 5.39 & $1.92^{*}$ & 4.88 & $1.70^{\star}$ & 0.27 & 0.18 & 0.24 & 0.12 & 6.04 & 2.03 & 12.11 & $3.20^{*}$ & 34.06 & 9.46 & 58.21 & 7.88 \\
\hline $\begin{array}{l}\text { Control } \\
(N=10)\end{array}$ & 9.73 & 2.14 & 8.43 & 1.27 & 0.83 & 0.68 & 0.48 & 0.22 & 7.83 & 2.45 & 17.43 & 6.58 & 42.89 & 12.97 & 54.91 & 1.00 \\
\hline
\end{tabular}

${ }^{*}$ Indicated $\mathrm{P}<0.05$ versus control.

Table 3. Blood chemistry data for the male rats treated with 2-bromopropane (2BP) for 28 days and of the control groups.

\begin{tabular}{|c|c|c|c|c|c|c|c|c|c|c|c|c|c|c|c|c|c|c|}
\hline \multirow[t]{2}{*}{ 2BP dose } & \multicolumn{2}{|c|}{$\begin{array}{c}\text { Aspartate } \\
\text { aminotrans- } \\
\text { ferase } \\
(\mu / 1) \\
\end{array}$} & \multicolumn{2}{|c|}{$\begin{array}{c}\text { Alanine } \\
\text { amino- } \\
\text { transferase } \\
(\mu / l)\end{array}$} & \multicolumn{2}{|c|}{$\begin{array}{c}\text { Alkaline } \\
\text { phosphatease } \\
(\mu / \mathrm{l})\end{array}$} & \multicolumn{2}{|c|}{$\begin{array}{l}\text { Protein } \\
(\mathrm{mg} / \mathrm{dl})\end{array}$} & \multicolumn{2}{|c|}{$\begin{array}{l}\text { Glucose } \\
(\mathrm{mg} / \mathrm{dl})\end{array}$} & \multicolumn{2}{|c|}{$\begin{array}{l}\text { Urea nitrogen } \\
\text { in blood } \\
\text { (mg/dl) }\end{array}$} & \multicolumn{2}{|c|}{$\begin{array}{l}\text { Creatitine } \\
(\mathrm{mg} / \mathrm{dl})\end{array}$} & \multicolumn{2}{|c|}{$\begin{array}{l}\text { Cholesterol } \\
(\mathrm{mmol} / \mathrm{l})\end{array}$} & \multicolumn{2}{|c|}{$\begin{array}{c}\text { Total } \\
\text { bilirubin } \\
(\mathrm{mg} / \mathrm{dl})\end{array}$} \\
\hline & Mean & SD & Mean & SD & Mean & $\mathrm{SD}$ & Mean & SD & Mean & SD & Mean & $\mathrm{SD}$ & Mean & $\mathrm{SD}$ & Mean & SD & Mean & SD \\
\hline $\begin{array}{l}125 \mathrm{mg} \\
(\mathrm{N}=10)\end{array}$ & 104.5 & $9.9^{*}$ & 35.2 & 5.8 & 85.7 & 12.2 & 5.1 & 0.2 & 114.9 & $11.1^{*}$ & 12.4 & $0.5^{*}$ & 0.33 & 0.02 & 21.8 & 3.0 & 0.05 & 0.01 \\
\hline $\begin{array}{l}250 \mathrm{mg} \\
(N=10)\end{array}$ & 101.9 & $10.7^{\star}$ & 33.3 & 4.4 & 77.5 & 16.0 & 5.1 & 0.5 & 116.9 & $18.3^{*}$ & 11.4 & $0.9^{*}$ & 0.37 & 0.04 & 21.1 & 3.6 & 0.07 & $0.02^{*}$ \\
\hline $\begin{array}{l}500 \mathrm{mg} \\
(\mathrm{N}=10)\end{array}$ & 106.5 & $18.7^{\star}$ & 33.0 & 17.7 & 48.0 & $11.1^{*}$ & 4.9 & 0.3 & 104.2 & 9.7 & 11.8 & $1.2^{*}$ & 0.39 & 0.05 & 29.3 & $4.1^{*}$ & 0.05 & 0.01 \\
\hline $\begin{array}{l}\text { Control } \\
(N=10)\end{array}$ & 130.2 & 21.2 & 36.0 & 3.1 & 90.6 & 19.5 & 5.1 & 0.2 & 101.1 & 10.0 & 14.5 & 2.6 & 0.41 & 0.05 & 22.0 & 3.9 & 0.05 & 0.01 \\
\hline
\end{tabular}

* Indicates $P<0.05$ versus control.

addition, no significant increases in urea nitrogen in blood and creatinine were detected (table 3 ). Increases in blood glucose were noted in the low- and middle-dose rats $(\mathrm{P}<0.05)$ (table 3$)$. Interestingly, the level of cholesterol increased in the high-dose group (table 3 ).

\section{Gross pathological examination}

Increasing atrophy of the testes was apparent from the low - to the high-dose group exposed to 2BP in comparison with the control group. Besides that for the testes, no other distinct features of gross pathology were observed.

\section{Histopathological examination}

One of the organs which displayed a distinctive decrease in body weight gain, absolute or relative, was the testis. Histopathological examination of the testes treated with the middle and high dose of 2BP showed a typical patch appearance with severely depleted atrophic tubules (figure $2 \mathrm{C}$ and $\mathrm{D}$ ), and germ cell necrosis of spermatogonia and spermatocytes was exhibited in the seminiferous tubules (figure $3 \mathrm{~B}$ ). The seminiferous tubules were left with only Sertoli cells, which showed extensive cytoplasmic vacuolization (figure $3 \mathrm{~B}$, arrows). Leydig cell hyperplasia or hypertrophy in the interstitial tissue was also noted (figure 3B, arrow heads). In the epididymis, the caput epithelium showed some degree of atrophy with vacuolization of the epididymal epithelium (figure $4 \mathrm{~B}$, arrows). The epididymal duct contained sloughed epithelial cells with sperm-cell aggregates (figure $4 \mathrm{~B}$, arrow heads). Occasionally, inflammatory cells were found in the lumen. Although other organs, such as the kidneys, the liver, and the pituitary, were examined histopathologically, no distinct histopathological findings were detected.

\section{Discussion}

Our study indicates that reproductive and hematopoietic toxicity were induced by 28 days of $2 \mathrm{BP}$ treatment. The weight loss of the testes was the most noticeable for the organs when the organ weight was normalized to $100 \mathrm{~g}$ of body weight. In addition, the histopathology of the testes showed severe pathological lesions when compared with that of the other organs, including necrosis of the spermatogonia and spermatocytes in the seminiferous tubules. It was also suggested that $2 \mathrm{BP}$ did not affect other organs, such as the liver and the kidney. The toxic- 


\begin{tabular}{|c|c|c|c|c|c|c|c|c|c|c|c|c|c|c|c|}
\hline \multicolumn{2}{|c|}{$\begin{array}{l}\text { Corpuscular } \\
\text { hemoglobin } \\
\text { (pg) }\end{array}$} & \multicolumn{2}{|c|}{$\begin{array}{c}\text { Corpuscular } \\
\text { hemoglobin } \\
\text { concentration }\end{array}$} & \multicolumn{2}{|c|}{$\begin{array}{l}\text { Red cell volume } \\
\text { distribution } \\
\text { width }\left(\mu^{3}\right) \\
\end{array}$} & \multicolumn{2}{|c|}{ PLT } & \multicolumn{2}{|c|}{$\begin{array}{l}\text { Mean platelet } \\
\text { volume }\end{array}$} & \multicolumn{2}{|c|}{$\begin{array}{l}\text { Percentage of } \\
\text { lymphocytes }\end{array}$} & \multicolumn{2}{|c|}{$\begin{array}{l}\text { Percentage of } \\
\text { monocytes }\end{array}$} & \multicolumn{2}{|c|}{$\begin{array}{l}\text { Percentage of } \\
\text { granulocytes }\end{array}$} \\
\hline Mean & $S D$ & Mean & SD & Mean & $\mathrm{SD}$ & Mean & $S D$ & Mean & SD & Mean & SD & Mean & SD & Mean & SD \\
\hline 19.24 & 2.59 & 35.42 & 4.46 & 18.89 & 3.74 & 1087.4 & 499.6 & 6.72 & 0.34 & 86.51 & 3.34 & 7.42 & 3.06 & 6.06 & 1.02 \\
\hline 20.00 & 1.67 & 36.73 & 3.87 & 18.11 & 3.76 & 941.1 & 321.0 & 6.50 & 0.29 & 86.84 & 9.31 & 7.17 & 4.82 & 5.99 & 4.58 \\
\hline 21.34 & 2.62 & 36.97 & 3.92 & 20.94 & 4.37 & 861.2 & 205.4 & 5.88 & $0.27^{*}$ & 91.06 & 2.68 & 4.82 & 1.74 & 4.12 & 1.77 \\
\hline 21.20 & 1.41 & 38.49 & 2.18 & 17.40 & 3.11 & 995.6 & 311.4 & 6.63 & 0.26 & 87.88 & 6.05 & 7.63 & 4.42 & 4.50 & 1.71 \\
\hline
\end{tabular}

Figuire 2. Histopathology of the testes of the rats treated with 2BP. Male rats were treated with $2 \mathrm{BP}$ concentrations of $0,125,250$, and $500 \mathrm{mg} / \mathrm{kg}$ for 28 days. The animals were killed, and the testes were removed and processed for histopathology. (A: vehicle control; B: 2BP at $125 \mathrm{mg} / \mathrm{kg}$, shows normal appearance of tubules; C: $2 \mathrm{BP}$ at $250 \mathrm{mg} / \mathrm{kg}$, shows tubular atrophy with a depletion of germ cell; D: 2BP at $500 \mathrm{mg} / \mathrm{kg}$ for 28 days, shows a typical patch appearance of severely depleted atrophic tubules). Note the atrophic seminiferous tubules in $C$ and $D$ in comparison with $A$. An apparentinc rease in interstitial Leydig cells can be seen ( $100 \times$ objective)
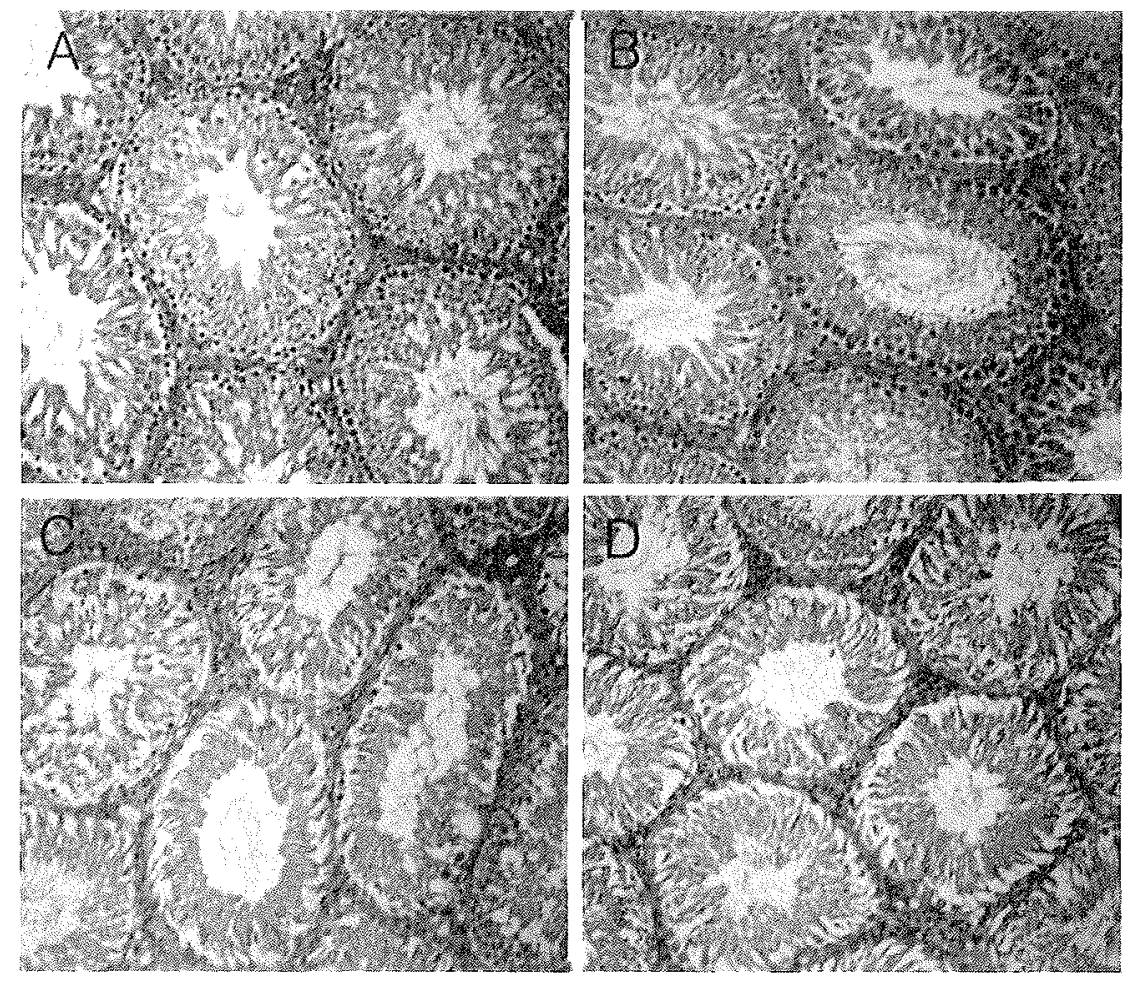

ity of $2 \mathrm{BP}$ was dose-dependent in that the higher doses exhibited more severe toxicity than the lower doses in our 28-day repeated dose experiments. Another recent experiment further indicated that $2 \mathrm{BP}$ treatment induced a delay of the estrous cycle of female Sprague Dawley rats (9). The $2 \mathrm{BP}$ treatment decreased ovarian weight and fertility and tended to decrease the number of pups born, depending on the dose (9). Therefore, together with our recent experiment on female rats, our data strongly support the conclusion that the causal agent for the bone marrow and reproductive toxicity of the electronic company workers might be $2 \mathrm{BP}$.

The other form of toxicity caused by $2 \mathrm{BP}$ is an aberration of the hematopoietic system. In our study, leuko- penia accompanied anemia, which was similar to that of the workers exposed to $2 \mathrm{BP}$ and diagnosed as pancytopenia (1). The anemia noted in the workers was macrocytic anemia, which increased the mean corpuscular volume and anisocytosis, which in turn exhibited an increase in the red cell distribution width (personal communication). These symptoms were usually noted in aplastic anemia patients or patients treated with cytotoxic drugs (10). It has been shown that the anemia caused by toxic chemicals increases the reticulocytes or erythrocyte progenitor cells in the circulating blood of animals and humans $(11-12)$. A micronucleus test carried out simultaneously with the 28-day, repeated dose, toxicity test for $2 \mathrm{BP}$ rats indicated that there was a sig- 

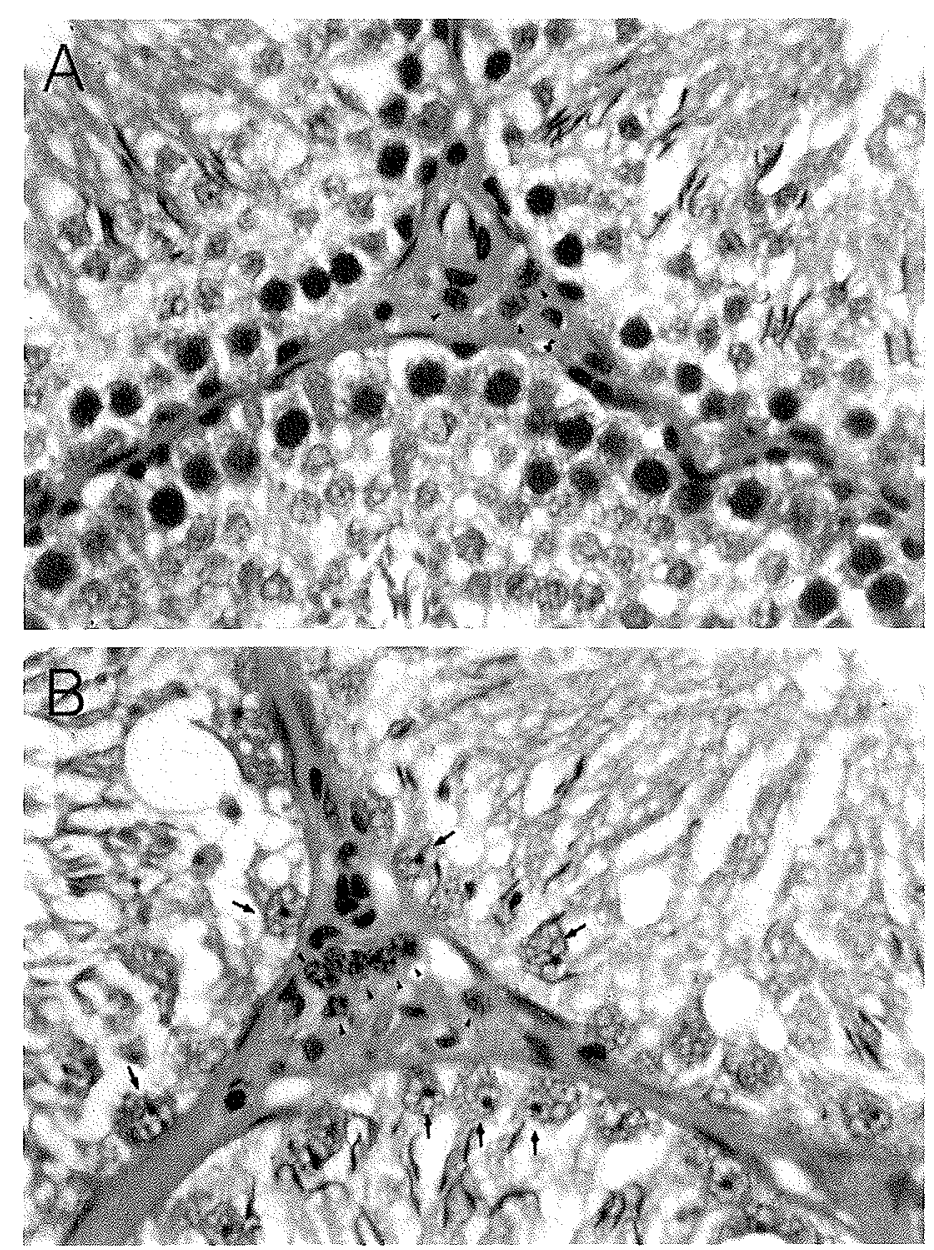

Figure 3. Depleted seminiferous tubules with interstitial Leydig cell hyperplasia. [A: vehicle control, shows normal tubules with healthy looking germ cells; B: 2BP at $500 \mathrm{mg} /$ $\mathrm{kg}$, severely depleted tubules were left with only Sertoli cells (arrows)]. Note the extensive vacuolization of the Sertoli cells. Interstitial Leydig cell hyperplasia can also be seen (arrow heads) $(400 \times$ objective) nificant decrease in the percentage of polychromatic erythrocytes in the total number of erythrocytes without an increase in the micronucleus frequencies (3). Together with this result, our results suggest that there may be bone marrow depression in hematopoiesis due to $2 \mathrm{BP}$ treatment.

It has been shown that exposure to dibromochloropropane (DBCP) caused severe reproductive functional damage in several workers. According to the follow-up study of DBCP, some exposed workers show high levels of follicle stimulating hormone (FSH) and luteinizing hormone even 17 years after the exposure (13). In the case of 2BP intoxication, the type of reproductive toxicity is very similar to that seen with DBCP. Many of the workers showed high levels of FSH and demonstrated difficulty in recovering reproductive functions even after the termination of 2BP exposure (1). Histopathological findings observed in DBCP-treated animals have shown severe injuries of the testicles, kidneys, and lungs (1417). The findings showed that the testicles completely atrophied along with irreversible spermatogenesis. The renal injury was characterized by proximal tubular necrosis in the outer medulla $(14,16)$. The $2 \mathrm{BP}$ treatment also showed histopathology similar to that of DBCP treatment, displaying testicular atrophy with extensive loss of germ cells in the atrophic seminiferous tubules. In an animal experiment using $\mathrm{DBCP}$, the reproductive toxicity was induced by a dose of $300 \mathrm{mg} / \mathrm{kg}$ in short durations (3-7 days) by intraperitoneal injection or $10 \mathrm{ppm}$ of $\mathrm{DBCP}$ exposure in the air for 14 days $(14,18)$. In contrast, the reproductive toxicity induced by $2 \mathrm{BP}$ required a higher concentration and a longer duration of exposure than DBCP. In fact, the results of our satellite experiment, which started at the same time as the 28-day repeated-dose experiment, showed that the atrophy of testes was irreversible, even though the treated animals $(500 \mathrm{mg} / \mathrm{kg})$ were given a recovery period of 6 weeks after the experiment (data not shown). Our histopathological findings and the case report data suggested that 2BP may also cause severe irreversible damage to the reproductive organs of heavily exposed workers, similar to that of DBCP.

Since we do not know the actual ambient concentration of 2BP in workplaces, it is difficult to determine the level of exposure causing reproductive toxicity. Our epidemiologic investigation team measured ambient con- 
Figure 4. Histopathology of the epididymis. [A: vehicle control, normal cauda epididymis with normal appearance of spermatid in the lumen; B: 2BP at $500 \mathrm{mg} / \mathrm{kg}$, vacuolization of epididymal epithelial cells (arrow heads) with many cells of spermatid aggregates (arrows) in the lumen (200 $\times$ objective)]

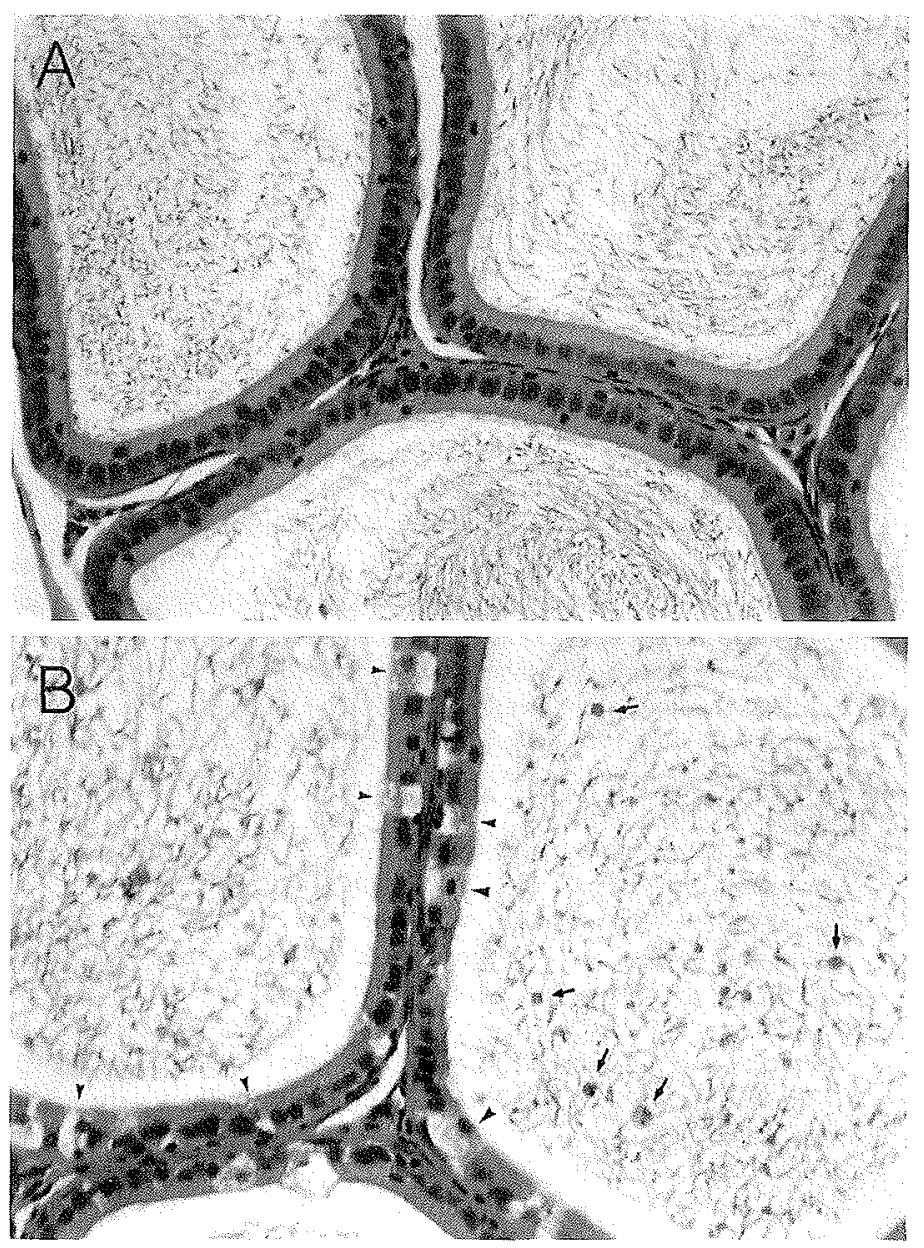

centrations of $2 \mathrm{BP}$ under simulated work conditions after the incident. The team found that the $2 \mathrm{BP}$ concentration was $9.2-19.6 \mathrm{ppm}$ in 14 stationary samples from the tactile switch assembling room (19). Occasionally, the workers experienced a very high short-term exposure level of several thousand parts per million during the manipulation of the cleaning solution baths, and some workers actually touched 2BP with their bare hands during the changing of the solvent (1). An epidemiologic study revealed that the ambient concentration of $2 \mathrm{BP}$ was maintained constantly since the workplace was not equipped with a proper ventilation system and was operated 24 hours a day for 7 days a week (19). It is suggested that the workers showing the symptoms of reproductive and hematopoietic toxicities might have been exposed to high levels of $2 \mathrm{BP}$ for a long duration (4-16 months) of time, as described in the case study.

The route of exposure, intraperitoneal, used in this experiment is not an actual route of exposure in workplaces. It might be disadvantageous from the risk assessment aspect when the route of administration is intraperitoneal because of toxicologic reasons; first-pass effects through the liver do not take place through inhalation routes. There may be other comparability problems also. Although the toxicology outcome could be changed due to different routes of exposure, our experiment reproduced the results of those found with exposed workers satisfactorily. Inhalation toxicity tests are required if the result of the intraperitoneal experiment is negative for toxicity. Since many toxicities of workers are reproducible using intraperitoneal exposure, the route of exposure may not be critical in this case.

\section{Acknowledgments}

This study was supported by a grant from the Korea Industrial Safety Corporation and the Ministry of Labor.

We acknowledge the assistance of Dr Jin Soo Han at the Samsung Biomedical Research Institute for analyzing the blood samples. We offer our sincere appreciation to the Japanese scientists involved in the 4 years of the Korean-Japanese Cooperative Project on the Prevention of Occupational Diseases for Korean Workers. Without the guidance and assistance given by the scientists of the 
Japan Bioassay Research Center, this work would not have been possible.

\section{References}

1. Kim Y, Jung K, Hwang $T$, Jung G, Kim H, Park J, et al. Hematopoietic and reproductive hazards of Korean electronic workers exposed to solvents containing 2-bromopropane. Scand J Work Environ Health 1996;22:387-91.

2. Kim HY, Chung YH, Yi KH, Kim JG, Yu IJ. LC50 of 2 bromopropane. Ind Health 1996;403-7.

3. Maeng SH, Yu IJ. Mutagenicity of 2-bromopropane. Ind Health 1997;35:87-95.

4. Japanese Association of Pathway. Handbook of pavement test method: method of test for extraction of asphalt from asphalt mixture. Tokyo: Japanese Association of Pathway, 1988

5. National Institute for Occupational Safety and Health (NIOSH). Registry of toxic effects of chemical substances (RTECS), RTEC number TX 4111000. Cincinnati (OH): NIOSH, 1995.

6. Korea Research Institute of Chemical Technology. Acute oral toxicity test of solvent \#5200 in rat. Taejon (Korea): Korea Research Institute of Chemical Technology, 1995.

7. Chemical Inspection and Testing Institute, Hita Research Laboratories. Acute oral toxicity test of solvent \#5200 in rat. Test number A16-0236. Hita (Japan): Chemical Inspection and Testing Institute, Hita Research Laboratories, 1995.

8. Chemical Inspection and Testing Institute, Hita Research Laboratories. Acute oral toxicity test of SPG6-AR in rat: test number A16-0237. Hita (Japan): Chemical Inspection and Testing Institute, Hita Research Laboratories, 1995.

9. Lim CH, Maeng SH, Lee JY, Chung YH, Kim TG, Park JH, et al. Effects of 2-bromopropane on the female reproductive function in Sprague-Dawley rats. Ind Health 1997;35:278 84.

10. Irons RD. Blood and bone marrow. In: Haschek WG, Rousseaux $\mathrm{CG}$, editors. Handbook of toxicologic pathology. San Diego (CA): Academic Press, 1991:389-419.

11. Rosin J, Bartosz G, Wronska-Nofer T. Studies on the effect of ethanol and/or toluene on rat erythrocytes. J Appl Toxicol 1988:8:369-72

12. Hee SQ, Biological monitoring an introduction. New York (NY): Van Nostrand Reinhold, 1993:230—99.

13. Potashnik G, Porath A. Dibromochloropropane (DBCP): a 17-year reassessment of testicular function and reproductive performance. J Occup Environ Med 1995;37(11):1287—92.

14. Saegusa J, Hiromichi H, Kawai K. Toxicity of 1,2-dibromo-3chloropropane (DBCP), I: histopathological examination of male rats exposed to DBCP vapor. Ind Health 1982;20:31523.

15. Saegusa J. Cumulative effects of 1,2-dibromo-3-chloropropane (DBCP) on kidney and testis. Ind Health 1989;27:4958.

16. Kluwe WM. Acute toxicity of 1,2-dibromo-3-chloropropane in the F344 male rat, I: dose response relationships and differences in routes or exposure. Toxicol Appl Pharmacol 1981;59: $71-83$.

17. Kluwe WM. II. Development and repair of the renal epididymal, testicular and hepatic lesions. Toxicol Appl Pharmacol $1981 ; 59: 84$

18. Saegusa J. Radiomimetic toxicity of 1,2-dibromo-3-chloropropane (DBCP). Ind Health 1986;34:1-14.

19. Park JS, Kim Y, Park DW, Choi KS, Park SH, Moon YH. An outbreak of hematopoietic and reproductive disorders due to solvents containing 2-bromopropane in an electronic factory, South Korea: epidemiological survey. J Occup Health. In press.

Received for publication: 31 October 1996 